\title{
Migration patterns of white sharks Carcharodon carcharias tagged at Guadalupe Island, Mexico, and identification of an eastern Pacific shared offshore foraging area
}

\author{
Michael L. Domeier*, Nicole Nasby-Lucas \\ Pfleger Institute of Environmental Research,901-B Pier View Way, Oceanside, California 92054, USA \\ Present address: Marine Conservation Science Institute, 2809 S. Mission Road, Fallbrook, California 92028, USA
}

\begin{abstract}
Pop-up satellite archival tags (PSATs) were used to study the migration patterns and habitat preference of 56 white sharks tagged off Guadalupe Island, Mexico, between 2000 and 2008. Nine tags were recovered, providing $1021 \mathrm{~d}$ of high resolution (2 min) archival data. Two individual sharks were tagged in consecutive years, providing $2 \mathrm{yr}$ of tracking data for each individual. White sharks were found to make long-range, seasonal migrations from Guadalupe Island to an offshore pelagic habitat, sometimes traveling as far west as the Hawaiian Islands. The pelagic region inhabited by Guadalupe Island white sharks corresponds with that reported for sharks tagged off central California; thus we have termed it the Shared Offshore Foraging Area (SOFA). Sharks spent at least 5 mo off Guadalupe Island before beginning their migration around 15 February on average (earliest 21 December, latest 5 May). They traveled through a migration corridor in an average time of $16 \mathrm{~d}$ at an average speed of $3.2 \mathrm{~km} \mathrm{~h}^{-1}$ and remained in the SOFA for an average duration of $140 \mathrm{~d}$. Males and females began their offshore migrations around the same time and traveled to the same area, but males were found to return to Guadalupe Island on average around 22 July (earliest 15 July, latest 30 July), while females remained in the SOFA into early autumn. Diving profiles of sharks in the SOFA strongly suggest feeding behavior; however, the targeted prey species are unknown this time.
\end{abstract}

KEY WORDS: Carcharodon · Migration · Aggregation · Guadalupe Island · White shark · Behavior · Philopatry

\section{INTRODUCTION}

The white shark Carcharodon carcharias is a large apex predator found globally in temperate and tropical oceans. Adult white sharks feed on both fishes and marine mammals (Compagno 1984), and are known to seasonally aggregate and feed around pinniped colonies. Such aggregations occur in temperate waters and have been described off the coasts of Australia (Bruce 1992), South Africa (Ferreira \& Ferreira 1996), California (Ainley et al. 1985), and Baja California, Mexico (Domeier \& Nasby-Lucas 2007). Once thought to be a coastal species (Compagno 1984, Klimley 1985), recent advances in electronic tagging technology have shown that white sharks are capable of long-range oceanic migrations. The use of pop-up satellite archival tags (PSATs) on white sharks off South Africa and the west coast of the United States (Boustany et al. 2002, Bonfil et al. 2005, Weng et al. 2007a) have demonstrated that they can cross ocean basins and utilize pelagic habitats for months at a time.

White sharks have been recognized as particularly vulnerable to rapid stock declines (IUCN Red List rating as 'Vulnerable', Hilton-Taylor 2000) and were listed in the 2005 Convention of the International Trade in Endangered Species of Wild Flora and Fauna 
(CITES) Appendix 2, based on their low intrinsic rate of population increase (Cailliet et al. 1985, Francis 1996, Pratt 1996, Smith et al. 1998, Compagno 2001) and natural rarity. Despite the large amount of behavioral data recently accumulated on this species, relatively little is known about its reproductive cycle.

A recently described white shark aggregation site off Guadalupe Island, Mexico (Domeier \& NasbyLucas 2007) was the site of an 8 yr electronic tagging project designed to study the movement patterns and habitat preferences of this population. Guadalupe Island is a sheer volcanic island $407 \mathrm{~km}$ south-southwest of San Diego, California, and $260 \mathrm{~km}$ offshore from Baja California, Mexico. The island rises out of deep water $(>3500 \mathrm{~m})$, stretches $41 \mathrm{~km}$ in a north/ south direction and is $15 \mathrm{~km}$ across at the widest point. Guadalupe Island is both a Mexican nature preserve (dedicated in 1925) and a pinniped sanctuary (since 1975). The island serves as a haulout and pupping site for the northern elephant seal Mirounga angustirostris, the Guadalupe fur seal Arctocephalus townsendi, and the California sea lion Zalophus californianus. A previous photo-ID study (Domeier \& Nasby-Lucas 2007) identified 73 individual white sharks of Guadalupe Island (at the time of this publication, the number had reached 87) and determined that individual sharks visit the island each year between the months of July and January. The use of PSAT technologies allowed us to (1) examine the exact timing of departure and arrival at the island, (2) determine where these sharks were going once they left the island, (3) examine behavioral differences in the offshore environment versus the nearshore habitat, and (4) look at differences in seasonal movement patterns between males and females.

A better understanding of the long-range migration patterns and areas of aggregation will hopefully allow us to better understand the life cycle of these sharks and aid in the management of this threatened species. We present results gathered from 75 PSATs deployed on white sharks off Guadalupe Island between the years 2000 and 2008.

\section{MATERIALS AND METHODS}

Tagging was performed between 2000 and 2007 at the northeastern and southeastern corners of Guadalupe Island, Mexico (see Table 1). Sharks were tagged using PSATs manufactured by Wildlife Computers (WC) and Microwave Telemetry (MT). Each shark was lured alongside the research vessel with fresh dead tuna and then tagged (hand held tagging pole) by inserting a metal or nylon tag head into the dorsal musculature at the base of the dorsal fin. As the pro- gram evolved, many different methods of tag rigging were attempted, but the majority of tags were rigged with an umbrella-style dart (described in Domeier et al. 2005) and $136 \mathrm{~kg}$ test Sufix Superior monofilament (Yao I Fabric). Beginning in 2005, all tags were rigged with $113 \mathrm{~kg}$ test nylon coated braided stainless steel leader (Sevenstrand). Sharks were photographed below the water surface to determine the sex and identify the individual whenever possible (Domeier \& Nasby-Lucas 2007).

Both WC and MT tags attach to the individual until a pre-programmed date and time when they activate an electrolytic release mechanism, float to the surface and transmit data to the Argos satellites. WC tags were programmed to collect data every $2 \mathrm{~min}$, and then summarize the depth and temperature data into bins of up to $24 \mathrm{~h}$ for transmission to the Argos satellites. For recovered tags, it was possible to access the entire 2 min resolution archival dataset. MT tags collected data at $1 \mathrm{~h}$ intervals and the tags transmitted these raw data.

In total, 75 PSATs (16 MT and 59 WC) were deployed on white sharks between 2000 and 2007 (2000: $\mathrm{n}=11$; 2001: $\mathrm{n}=7 ;$ 2002: $\mathrm{n}=9$; 2003: $\mathrm{n}=18 ; 2004: \mathrm{n}=12$; 2005: $n=15 ; 2007: \mathrm{n}=3)$. Tags were deployed during the months of August $(\mathrm{n}=26)$, November $(\mathrm{n}=2)$, December $(\mathrm{n}=45)$ and January $(\mathrm{n}=2)$ (see Table 1$)$. Several sharks were double-tagged (2003: $\mathrm{n}=1 ; 2004$ $\mathrm{n}=2 ; 2005: \mathrm{n}=5$ ), with the first tag set to release in May and the second tag set to release in late summer or early autumn. Analyzed data are reported as means $\pm \mathrm{SD}$, unless otherwise indicated.

When possible, estimates of shark lengths were made from the deck of the vessel with the known dimensions of the vessel as a guide. Length estimates were assumed to be rough and were used solely as a means to assess sexual maturity. Sexual maturity was based on total length and was designated for males of at least $3.6 \mathrm{~m}$ and females of at least $4.5 \mathrm{~m}$ in length (Francis 1996).

Tracks for each individual were determined using the tag manufacturers' light-based calculations for longitude and the PSAT Tracker algorithm (Domeier et al. 2005) that improves light-based geolocation estimates of latitude by matching sea surface temperature (SST) data from the tag with those measured from satellites. Since longitude estimates are much more reliable than those for latitude, and migration was primarily in an east-west direction, longitude was used to indicate the occurrence and timing of migration.

Calculated position points from tracks for all tag data (where the tags were on the sharks for more than $90 \mathrm{~d}$ ) were analyzed to examine tagged shark spatial use during 4 northern hemisphere astronomical seasons. In 
addition, offshore pop-up locations from this study and that of Weng et al. (2007a) were combined to analyze spatial use of the mixed population. Pop-up points around Guadalupe Island were also plotted to examine spatial use around the island. Utilization distribution analyses were performed using the fixed kernel method (Worton 1989) with the home range extension (Rodgers \& Carr 1998) for ArcView 3.2 (ESRI). Results were displayed as volume contours $(25,50$ and $95 \%)$ indicating core regions of occupancy.

Data were divided into 5 distinct zones for analysis: these were (1) Guadalupe Island, (2) a migration corridor just west of Guadalupe Island, (3) an expansive pelagic region termed the Shared Offshore Foraging Area (SOFA), (4) a migration corridor leading from the SOFA to the Hawaiian Islands, and (5) the Hawaiian Islands. Bin data for all WC tags were combined and analyzed by zone. Mean $( \pm \mathrm{SD})$ for the data from each zone was calculated from the mean for each tag dataset within that zone. The standard deviation represents variation between individual sharks for that zone. Sharks were determined to be migrating when the longitude values maintained a continuous increase or decrease.

\section{RESULTS}

Of the 75 deployed tags, 56 produced useful data (Table 1), 16 never reported (8 MT, $8 \mathrm{WC}$ ), and 3 tags transmitted but did not produce a pop-up location or usable data. One of the 56 tags considered usable produced a pop-up location but no other data; since this tag popped up in the Hawaiian Islands, the limited data are significant. Days at liberty (DAL) (i.e. number of days that a tag remained attached to a shark) for tagged sharks with useable data ranged from 1 to $386 \mathrm{~d}$ (mean $=140.9 \pm 94.0$ ) with a total of $7893 \mathrm{DAL}$ (Table 1). Location estimates and pop-up locations for all tags ranged from Guadalupe Island to the Hawaiian Islands, approximately $4000 \mathrm{~km}$ westward from Guadalupe Island (Fig. 1). Five tags provided data for roundtrip migrations of white sharks away from Guadalupe Island, out to the SOFA, and back to Guadalupe Island.

Nine tags were physically recovered after periods of 15, 16, 85, 97, 119, 162, 239, 245, and $246 \mathrm{~d}$ (Table 1). The recovered tags ( $7 \mathrm{WC}$ and $2 \mathrm{MT}$ ) allowed analyses of high resolution data; we recovered 735120 and 4896 observations of $2 \mathrm{~min}$ and $1 \mathrm{~h}$ resolution

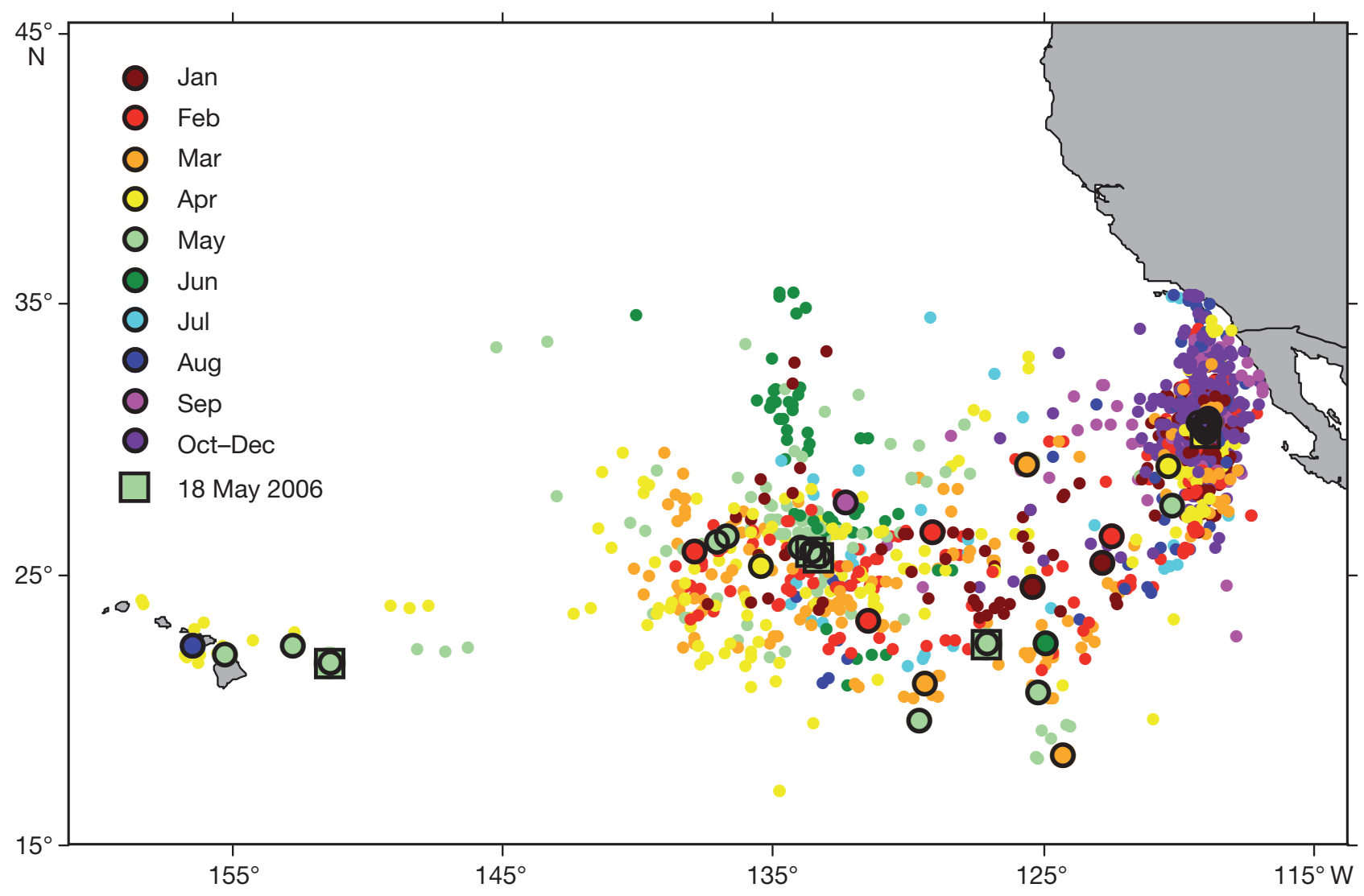

Fig. 1. Carcharodon carcharias. Pop-up locations and calculated track location points of all Pop-up Archival Satellite (PSAT) tags by month. Pop-up points are color-coded for each month. Fat outlines indicate pop-up points, thin outlines track locations. The 18 May $2007 \square$ denotes the spatial separation for 5 tags that popped up on the same date 
Table 1. Carcharodon carcharias. Individuals successfully tagged off Guadalupe Island Mexico, 2000-2005. DAL: Days at liberty, i.e. number of days that a tag remained attached to the shark. n/a: data not available. U: sex unknown; F: female; M: Male. Dates are month/day/year. Photo ID numbers from Domeier \& Nasby-Lucas (2007)

\begin{tabular}{|c|c|c|c|c|c|c|c|c|c|}
\hline $\begin{array}{l}\text { Tag No. } \\
\text { /sex }\end{array}$ & $\begin{array}{l}\text { Tagging } \\
\text { date }\end{array}$ & $\begin{array}{l}\text { Photo-ID } \\
\text { number }\end{array}$ & $\begin{array}{l}\text { Sexual } \\
\text { maturity }\end{array}$ & $\begin{array}{l}\text { Pop-up } \\
\text { date }\end{array}$ & DAL & $\begin{array}{l}\text { Date left } \\
\text { island }\end{array}$ & $\begin{array}{l}\text { Date } \\
\text { returned }\end{array}$ & $\begin{array}{l}\text { Pop-up } \\
\text { latitude }{ }^{\circ} \mathrm{N}\end{array}$ & $\begin{array}{c}\text { Pop-up } \\
\text { longitude }{ }^{\circ} \mathrm{W}\end{array}$ \\
\hline $1 \mathrm{U}$ & $1 / 7 / 00$ & & $\mathrm{n} / \mathrm{a}$ & $05 / 05 / 00$ & 119 & & & 26.01 & 119.56 \\
\hline $2 \mathrm{U}$ & $8 / 9 / 00$ & & yes & $08 / 31 / 00$ & 22 & & & $\mathrm{n} / \mathrm{a}$ & $\mathrm{n} / \mathrm{a}$ \\
\hline $3 \mathrm{U}$ & $8 / 9 / 00$ & & $\mathrm{n} / \mathrm{a}$ & 02/09/01 & 184 & $01 / 26 / 01$ & & 21.62 & 131.16 \\
\hline $4 \mathrm{U}$ & 8/9/00 & & no & 02/09/01 & 184 & & & 29.02 & 118.32 \\
\hline $5 \mathrm{U}$ & $8 / 10 / 00$ & & no & $09 / 13 / 00$ & 34 & & & 28.83 & 117.94 \\
\hline $6 U$ & $8 / 26 / 00$ & & $\mathrm{n} / \mathrm{a}$ & $08 / 26 / 00$ & 1 & & & 28.90 & 118.21 \\
\hline $7 \mathrm{U}$ & $8 / 26 / 00$ & & no & 09/20/00 & 25 & & & 28.91 & 118.24 \\
\hline $8 \mathrm{U}$ & $11 / 8 / 00$ & & $\mathrm{n} / \mathrm{a}$ & $12 / 11 / 00$ & 33 & & & 29.16 & 118.28 \\
\hline $9 \mathrm{U}$ & $11 / 9 / 00$ & & yes & 04/02/01 & 144 & 01/5/01 & & $\mathrm{n} / \mathrm{a}$ & $\mathrm{n} / \mathrm{a}$ \\
\hline $10 \mathrm{U}$ & $1 / 4 / 01$ & & yes & 03/17/01 & 72 & & & 28.96 & 118.30 \\
\hline $11 \mathrm{~F}$ & $8 / 12 / 01$ & & no & $08 / 27 / 01$ & $15^{\mathrm{a}}$ & & & 28.95 & 118.22 \\
\hline $12 \mathrm{U}$ & $8 / 12 / 01$ & & $\mathrm{n} / \mathrm{a}$ & 09/03/01 & 22 & & & 28.97 & 118.32 \\
\hline $13 \mathrm{M}$ & $8 / 12 / 01$ & 56 & yes & 09/21/01 & 40 & & & 28.84 & 118.12 \\
\hline $14 \mathrm{U}$ & $8 / 15 / 01$ & & $\mathrm{n} / \mathrm{a}$ & $11 / 07 / 01$ & 84 & & & 28.87 & 118.34 \\
\hline $15 \mathrm{U}$ & $8 / 15 / 01$ & & $\mathrm{n} / \mathrm{a}$ & $02 / 01 / 02$ & 170 & 01/29/02 & & 23.83 & 122.24 \\
\hline $16 \mathrm{M}$ & $8 / 12 / 02$ & 17 & no & $11 / 17 / 02$ & $97^{a}$ & & & 29.15 & 118.28 \\
\hline $17 \mathrm{~F}$ & $12 / 5 / 02$ & & yes & $03 / 18 / 03$ & 103 & 03/12/03 & & 27.60 & 125.11 \\
\hline $18 \mathrm{M}$ & $12 / 5 / 02$ & 19 & yes & 08/08/03 & $246^{\mathrm{a}}$ & $02 / 2 / 03$ & $7 / 28 / 03$ & 28.91 & 118.23 \\
\hline $19 \mathrm{U}$ & $12 / 5 / 02$ & & yes & 08/13/03 & 251 & $\mathrm{n} / \mathrm{a}$ & & 20.64 & 156.90 \\
\hline $20 \mathrm{U}$ & 8/8/03 & & $\mathrm{n} / \mathrm{a}$ & $11 / 01 / 03$ & $85^{\mathrm{a}}$ & & & 29.14 & 118.28 \\
\hline $21 \mathrm{M}$ & 8/8/03 & 19 & yes & 08/28/04 & 386 & $02 / 2 / 04$ & $7 / 14 / 04$ & $\mathrm{n} / \mathrm{a}$ & $\mathrm{n} / \mathrm{a}$ \\
\hline $22 \mathrm{M}$ & 8/9/03 & 7 & yes & $12 / 06 / 03$ & $119^{\mathrm{a}}$ & & & 29.15 & 118.28 \\
\hline $23 \mathrm{U}$ & 8/10/03 & & $\mathrm{n} / \mathrm{a}$ & $11 / 29 / 03$ & 111 & & & 28.94 & 118.32 \\
\hline $24 \mathrm{U}$ & $8 / 10 / 03$ & & yes & 05/17/04 & 281 & 01/10/04 & & 24.40 & 133.74 \\
\hline $25 \mathrm{U}$ & $8 / 11 / 03$ & & $\mathrm{n} / \mathrm{a}$ & $05 / 24 / 04$ & 287 & $\mathrm{n} / \mathrm{a}$ & & 24.83 & 136.54 \\
\hline $26 \mathrm{M}$ & $8 / 11 / 03$ & 68 & yes & $08 / 11 / 04$ & 366 & $01 / 7 / 04$ & $7 / 25 / 04$ & 29.14 & 118.20 \\
\hline $27 \mathrm{M}$ & $12 / 5 / 03$ & 10 & no & $01 / 05 / 04$ & 31 & & & 29.16 & 118.26 \\
\hline $28 \mathrm{M}$ & $12 / 5 / 03$ & 19 & yes & $04 / 03 / 04$ & 120 & $02 / 2 / 04$ & & 23.71 & 135.28 \\
\hline $29 \mathrm{M}$ & $12 / 5 / 03$ & 13 & yes & $06 / 29 / 04$ & 207 & $\mathrm{n} / \mathrm{a}$ & & 20.77 & 124.41 \\
\hline $30 \mathrm{M}$ & $12 / 5 / 03$ & 10 & no & 08/06/04 & $245^{\mathrm{a}}$ & 05/5/04 & $7 / 30 / 04$ & 29.15 & 118.28 \\
\hline $31 \mathrm{M}$ & $12 / 6 / 03$ & 7 & yes & $02 / 01 / 04$ & 57 & $01 / 22 / 04$ & & 24.99 & 128.67 \\
\hline $32 \mathrm{M}$ & $12 / 6 / 03$ & 8 & no & $02 / 28 / 04$ & 84 & $02 / 25 / 04$ & & 24.81 & 121.84 \\
\hline $33 \mathrm{~F}$ & 12/6/03 & 5 & no & $10 / 08 / 04$ & 307 & $\mathrm{n} / \mathrm{a}$ & $\mathrm{n} / \mathrm{a}$ & 29.27 & 119.36 \\
\hline $34 \mathrm{~F}$ & $12 / 10 / 04$ & 39 & yes & $09 / 11 / 05$ & 275 & $02 / 5 / 05$ & & 26.15 & 132.02 \\
\hline $35 \mathrm{M}$ & $12 / 11 / 04$ & 21 & $\mathrm{n} / \mathrm{a}$ & 04/18/05 & 128 & & & 29.16 & 118.15 \\
\hline $36 \mathrm{~F}$ & $12 / 11 / 04$ & 44 & $\mathrm{n} / \mathrm{a}$ & 05/11/05 & 151 & 03/1/05 & & 24.60 & 136.93 \\
\hline $37 \mathrm{U}$ & $12 / 12 / 04$ & & $\mathrm{n} / \mathrm{a}$ & $12 / 28 / 04$ & $16^{\mathrm{a}}$ & & & 29.27 & 118.18 \\
\hline $38 \mathrm{M}$ & $12 / 12 / 04$ & 13 & yes & 04/13/05 & 122 & $\mathrm{n} / \mathrm{a}$ & & 27.50 & 119.68 \\
\hline $39 \mathrm{U}$ & $12 / 12 / 04$ & & $\mathrm{n} / \mathrm{a}$ & 05/11/05 & 150 & $\mathrm{n} / \mathrm{a}$ & & 20.23 & 125.93 \\
\hline $40 \mathrm{M}$ & $12 / 12 / 04$ & 10 & no & 08/08/05 & $239^{a}$ & 04/7/05 & $7 / 15 / 05$ & 29.15 & 118.28 \\
\hline $41 \mathrm{~F}$ & 12/7/05 & 64 & $\mathrm{n} / \mathrm{a}$ & 05/18/06 & $162^{\mathrm{a}}$ & $02 / 10 / 06$ & & 20.03 & 151.63 \\
\hline $42 \mathrm{~F}$ & $12 / 7 / 05$ & 64 & $\mathrm{n} / \mathrm{a}$ & 05/19/06 & 163 & $02 / 10 / 06$ & & 20.66 & 153.12 \\
\hline $43 \mathrm{~F}$ & $12 / 8 / 05$ & 1 & $\mathrm{n} / \mathrm{a}$ & 03/17/06 & 99 & 02/23/06 & & 16.52 & 123.72 \\
\hline $44 \mathrm{M}$ & $12 / 8 / 05$ & 11 & $\mathrm{n} / \mathrm{a}$ & $12 / 27 / 05$ & 19 & & & 29.00 & 118.45 \\
\hline $45 \mathrm{M}$ & $12 / 8 / 05$ & 11 & $\mathrm{n} / \mathrm{a}$ & 05/18/06 & 161 & 3/28/06 & & 20.73 & 126.61 \\
\hline $46 \mathrm{M}$ & 2/8/05 & 13 & yes & $05 / 18 / 06$ & 161 & 02/4/06 & & 24.07 & 133.03 \\
\hline $47 \mathrm{M}$ & $12 / 8 / 05$ & & $\mathrm{n} / \mathrm{a}$ & $03 / 27 / 06$ & 109 & $\mathrm{n} / \mathrm{a}$ & & 19.21 & 128.99 \\
\hline $48 \mathrm{M}$ & $12 / 8 / 05$ & 19 & yes & 05/18/06 & 161 & 01/23/06 & & 24.26 & 133.34 \\
\hline $49 \mathrm{M}$ & $12 / 8 / 05$ & 19 & yes & $06 / 29 / 06$ & 203 & $01 / 23 / 06$ & & 25.06 & 133.10 \\
\hline $50 \mathrm{M}$ & $12 / 8 / 05$ & 26 & yes & 05/18/06 & 161 & & & 28.82 & 118.29 \\
\hline $51 \mathrm{M}$ & 2/8/05 & 26 & yes & $10 / 18 / 06$ & 314 & & & $\mathrm{n} / \mathrm{a}$ & $\mathrm{n} / \mathrm{a}$ \\
\hline $52 \mathrm{M}$ & $12 / 8 / 05$ & 46 & yes & $02 / 21 / 06$ & 75 & 01/16/06 & & 24.26 & 137.76 \\
\hline $53 \mathrm{M}$ & $12 / 8 / 05$ & 61 & $\mathrm{n} / \mathrm{a}$ & $05 / 01 / 06$ & 144 & $02 / 14 / 06$ & & 20.29 & 155.72 \\
\hline $54 \mathrm{M}$ & $12 / 6 / 07$ & 85 & no & 05/11/08 & 157 & $04 / 22 / 08$ & & 17.80 & 129.20 \\
\hline $55 \mathrm{M}$ & $12 / 8 / 07$ & 79 & yes & 05/11/08 & 155 & 04/24/08 & & 18.84 & 124.65 \\
\hline $56 \mathrm{~F}$ & $12 / 8 / 07$ & 47 & no & $01 / 13 / 08$ & 36 & $12 / 21 / 07$ & & 22.92 & 124.92 \\
\hline
\end{tabular}


data, respectively. Three archival datasets (2 min resolution) documented roundtrip migrations that originated and ended off Guadalupe Island, two of which were from the same individual in consecutive years. Another recovered tag provided a 2 min resolution dataset documenting the movement of a shark from Guadalupe to a position $332 \mathrm{~km}$ east of the Hawaiian Islands (Fig. 2).

Calculated tracks from tagged white sharks revealed a seasonal movement pattern that extended from Guadalupe Island to as far west as the Hawaiian Islands (Figs. 1 to 3 ). Seasonal spatial use analysis showed that the sharks spent autumn and early winter months in an insular habitat, began an offshore pelagic phase in winter to mid-spring, occasionally traveling as far as the Hawaiian Islands, and returned to Guadalupe Island by mid to late summer (Fig. 3). Since movement between Guadalupe Island, the pelagic habitat, and the Hawaiian Islands was primarily east-to-west, plotting longitude estimates over time created an accurate representation of the timing and extent of migration (Fig. 4).

Rough length estimates of tagged individuals were made during 39 of the tagging events to provide information on the size structure of this population. Sharks varied in total length from 2.4 to $5.2 \mathrm{~m}$, and most were $>3.5 \mathrm{~m}$ long (10 sharks $<3.5 \mathrm{~m}[26 \%$ ], 20 between 3.5 and $4.5 \mathrm{~m} \mathrm{[51 \% ],} \mathrm{and} 9$ sharks $>4.5 \mathrm{~m}$ $[23 \%])$. For those sharks where sex was verified, the length of 2 females and 5 males was estimated between 2.5 and $3.5 \mathrm{~m}, 1$ female and 9 males were estimated between 3.5 and $4.5 \mathrm{~m}$, and 2 females and 2 males were estimated between 4.5 and $5.5 \mathrm{~m}$. In this sample of the population, $69 \%$ of the males were sexually mature, compared to only $40 \%$ of the females.
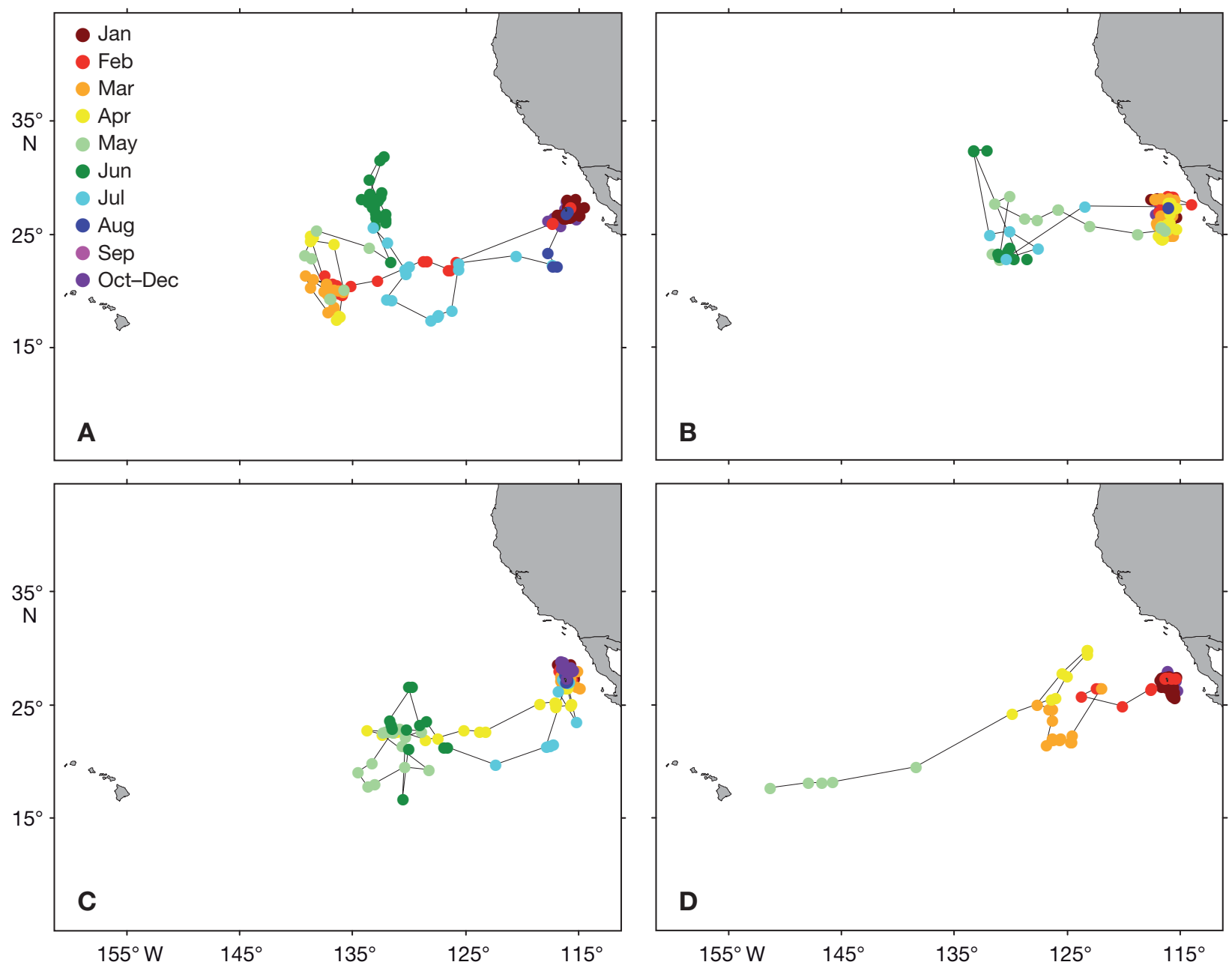

Fig. 2. Carcharodon carcharias. Calculated tracks of 4 recovered white shark tags showing 3 roundtrip migrations for (A) tag 18M, (B) tag 30M, (C) tag 40M and (D) 1 migration where the tag popped up just east of Hawaii, tag 41F. Colors indicate months. See Table 1 for tag details 

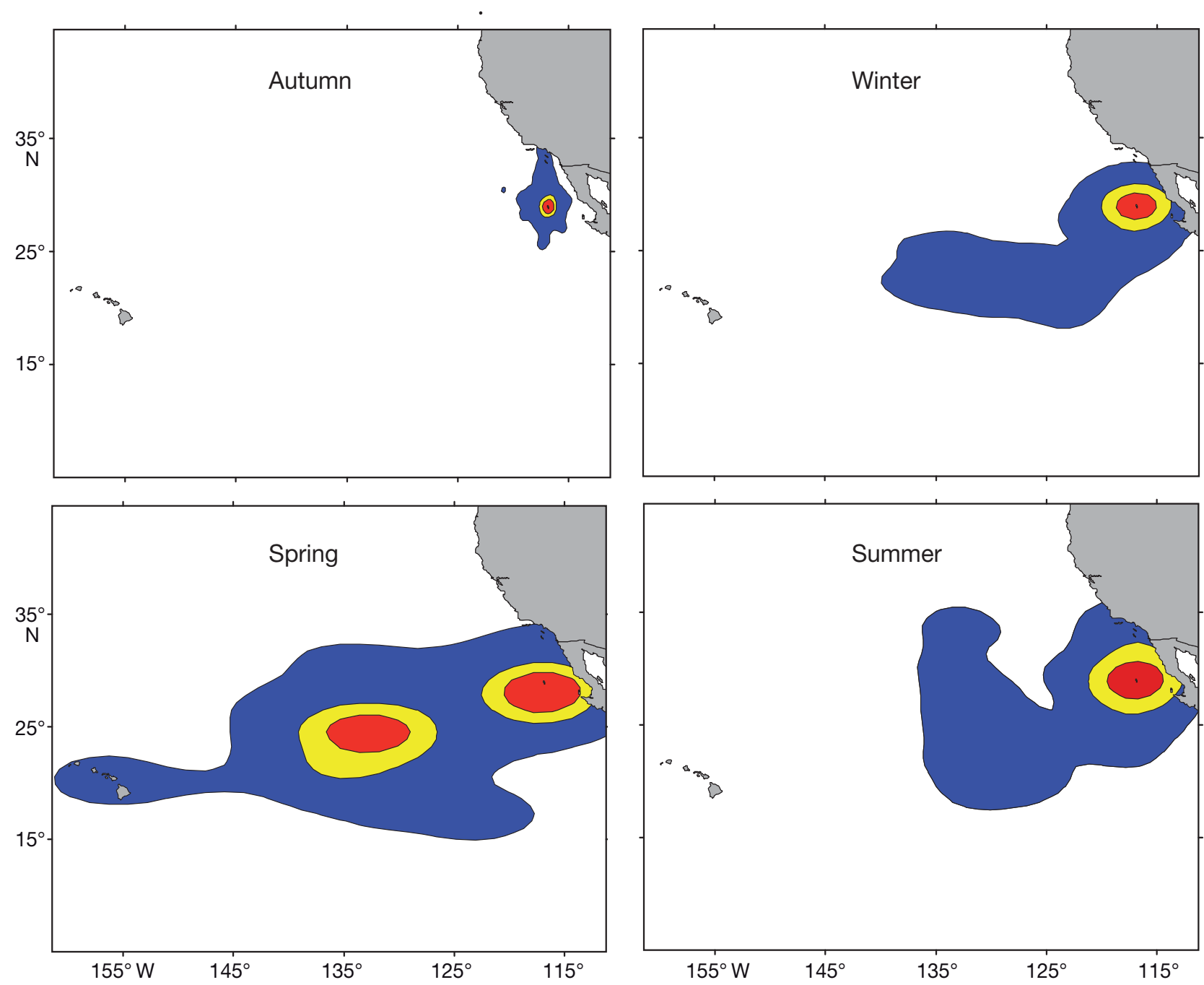

Fig. 3. Carcharodon carcharias. Kernel volume contours for tagged white sharks where days at liberty (DAL) were $>90$ (n $=36$ ), displaying core use regions during 4 seasons. Red $=25 \%$, yellow $=50 \%$ and blue $95 \%$ of all positions

\section{Zone 1: Guadalupe Island}

Movement patterns and utilization of Guadalupe Island

Satellite tagging data showed that white sharks seasonally visit and remain near Guadalupe Island. Sharks arrived there as early as July and remained for a minimum of 5 and a maximum of 8 mo before departing as early as December and as late as May. Nineteen of 26 sharks tagged in the month of August provided usable data with DAL between 1 and $386 \mathrm{~d}$ (mean: $132.3 \pm 121.0$ d). Individuals tagged in early August, near the time of first arrival, remained at the island for an average of $164 \pm 11.5 \mathrm{~d}$ prior to departing $(\mathrm{n}=5$, calculated from only those tags that were retained through the beginning of migration). We have no data to indicate that sharks remain at the island year-round; however, one tagged shark (tag 51M) was at Guadalupe Island on 22 May 2005 and again on 7 July 2005 with no position data between these dates to indicate whether or not it left the island. Geolocation estimates from tag data are not precise enough to provide information on the spatial distribution of sharks around Guadalupe Island; however, 21 tag pop-up positions from Guadalupe Island do show clusters of points at our 2 study sites as well as a grouping of positions off the southwestern portion of the island (Fig. 5).

Departure from the island was not coordinated, with sharks departing over a period of 19 wk between 21 December and 5 May, with individuals departing on average around 15 February ( $\mathrm{n}=25$ ) (Fig. 4). For sharks of known sex, departure dates of males were spread over a longer period (7 January through 5 May, $\mathrm{n}=15$ ) than those of females (21 December through 12 March, $n=6$ ), but the mean day of departure was not 


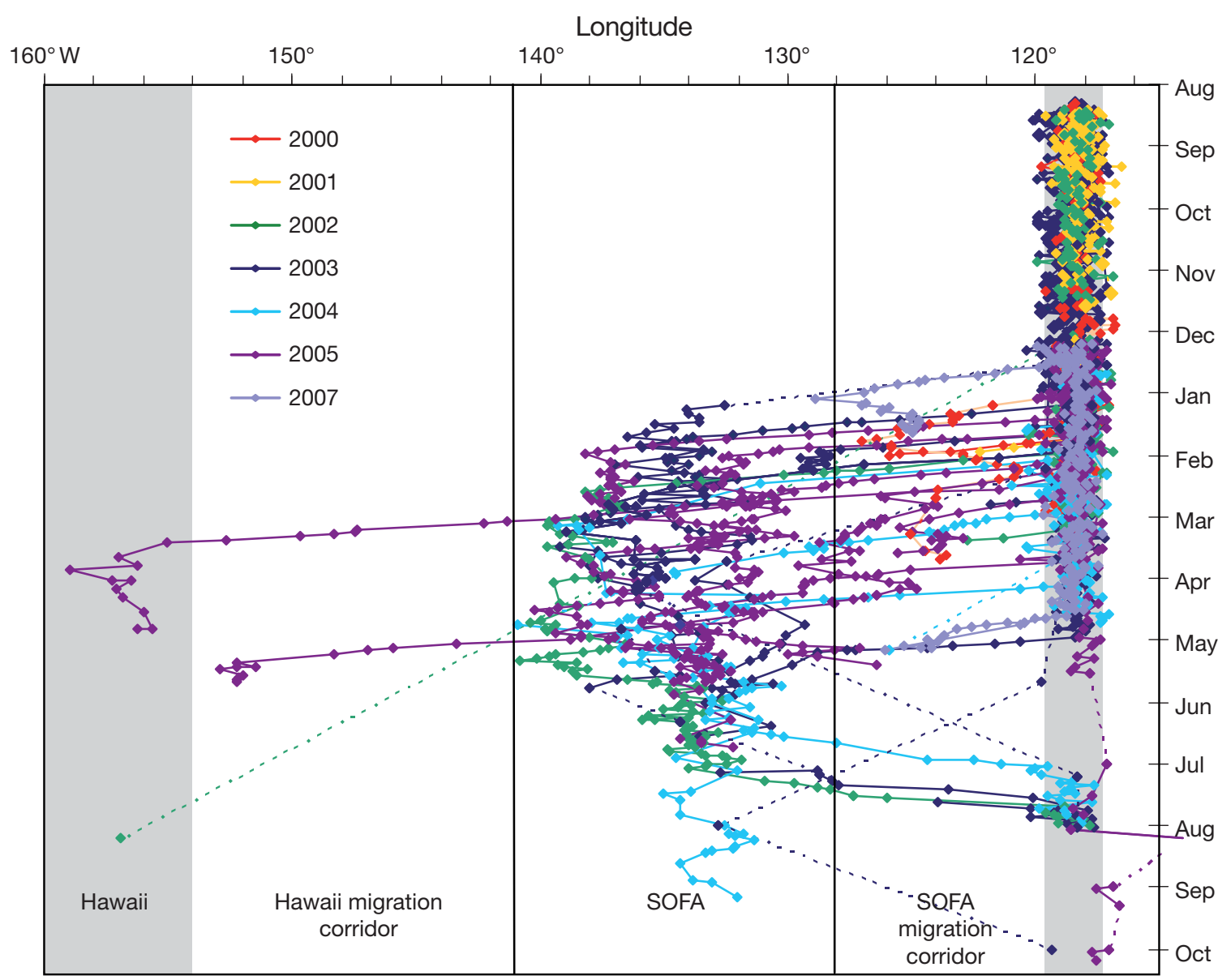

Fig. 4. Carcharodon carcharias. Plots of longitude points for tracks of tagged sharks versus month. Points are colored according to the year fish were tagged and indicate position in relation to Guadalupe Island, the Shared Offshore Foraging Area (SOFA) migration corridor, the SOFA, and Hawaii. Dashed lines: gap in location data $>14 \mathrm{~d}$. Shaded areas: locations of island habitats

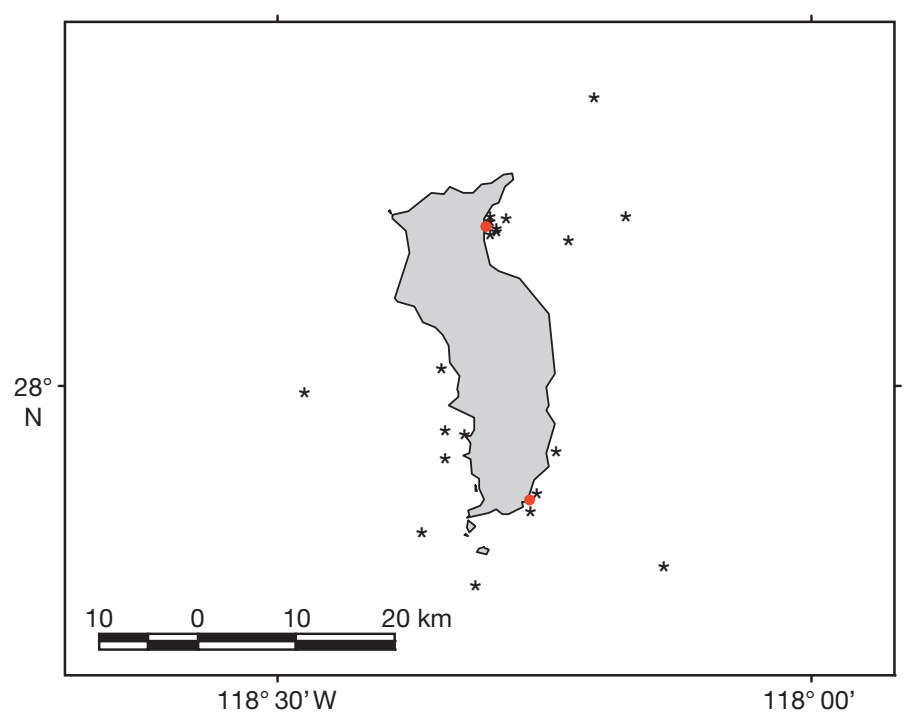

Fig. 5. Carcharodon carcharias. Map of PSAT pop-up points around Guadalupe Island $(\mathrm{n}=21)$. $\bullet$ : study sites significantly different (25 February and 11 February, respectively; $t$-test: $t=0.76, \mathrm{p}=0.46)$. In contrast, the return of males to the island was relatively synchronized; 5 tagged males returned in mid to late July (28 July 2003, 25 July 2004, 30 July 2004, 15 July 2005, and another with poor data that returned no later than 14 July 2004; Fig. 4), with a mean of 21 July. Only one female was documented to make a round trip migration (tag 33F, estimated to be a $3.2 \mathrm{~m}$ long shark); although the tag popped up off Guadalupe Island on 8 October, it transmitted very few data and the exact date of return to the island could not be determined. However, it is known that the shark was still in the SOFA $\left(132.8^{\circ} \mathrm{W}\right)$ on 4 August, suggesting it could not have arrived off Guadalupe earlier than late August. A second female (tag 34F) carried a tag until 11 September, at which time it was still in the SOFA $\left(132.0^{\circ} \mathrm{W}\right)$ (it was not sighted off Guadalupe Island that year in the photo-ID study, but was sighted off the island the following year) . 


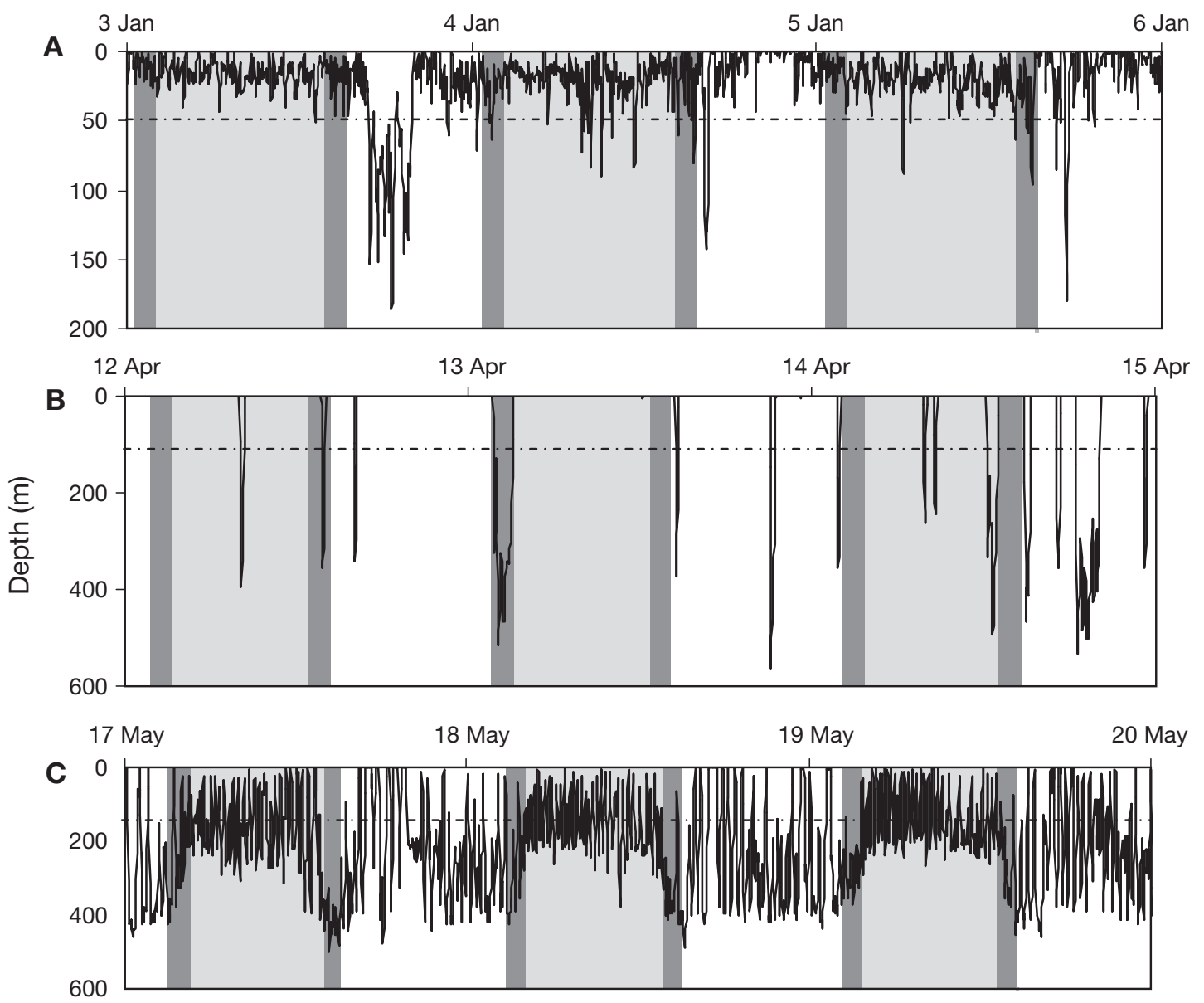

Fig. 6. Carcharodon carcharias. Representative depth $(\mathrm{m})$ and temperature profiles, recorded at 2 min intervals, for a white shark with tag 40M while (A) at Guadalupe Island, (B) migrating offshore and (C) in the Shared Offshore Foraging Area (SOFA). The dashed horizontal line represents the depth of the mixed layer $(\mathrm{m})$. Light grey denotes twilight and dark grey denotes nighttime. See Table 1 for tag details

Depth and temperature data

Sharks made frequent shallow dives within the mixed layer while off Guadalupe Island (Fig. 6A). The depth of the mixed layer during this period ranged from 40 to $100 \mathrm{~m}$, with an average of $60 \mathrm{~m}$. While at Guadalupe Island, the mean depth recorded by the 7 recovered WC tags was $40.7 \pm 55.7 \mathrm{~m}(\mathrm{n}=360779)$. Night-time depths were constrained to the mixed layer, with $90 \%$ of the time spent above $60 \mathrm{~m}$, only $2 \%$ spent below $100 \mathrm{~m}$, and $10 \%$ at the surface (0 to $5 \mathrm{~m}$ ). During the day, the sharks also spent most of their time in the mixed layer, with $75 \%$ of their time above $60 \mathrm{~m}$, although they spent more of their time at the surface $(26 \%)$ and made more frequent dives below the mixed layer with more time $(17 \%)$ spent below $100 \mathrm{~m}$. These patterns represented a significant difference in diel behavior (Mann-Whitney rank sum test, p < 0.001)

Sea surface temperatures experienced by sharks off Guadalupe Island ranged from 15.3 to $23.1^{\circ} \mathrm{C}$ (mean = $18.1 \pm 1.5, \mathrm{n}=58401$ ), while overall temperatures experienced ranged from 6.6 to $23.1^{\circ} \mathrm{C}$ (mean $=16.3 \pm$ $2.4, \mathrm{n}=360779$ ). Combining all tag data collected while sharks were off Guadalupe Island (archival and transmitted/binned), the majority of time was spent between the surface and $60 \mathrm{~m} \mathrm{(83.2 \% )} \mathrm{(Fig.} \mathrm{7A)} \mathrm{and} \mathrm{at}$ temperatures between 15 and $20^{\circ} \mathrm{C}$ (79.1\%) (Fig. 7B).

\section{Zone 2: Migration Corridor}

Once sharks left Guadalupe Island, they moved west through the migration corridor. The migration corridor extends from Guadalupe Island to approximately $128^{\circ} \mathrm{W}$ longitude. While in this corridor, white sharks spent the majority of their time at the surface, with occasional deep dives. The mixed layer in this zone ranged from $50 \mathrm{~m}$ to $140 \mathrm{~m}$, with an average of $90 \mathrm{~m}$. The 4 sharks carrying the recovered WC tags spent $61.2 \%$ of their time between 0 and $5 \mathrm{~m}$, an average total depth of $17.2 \pm 4.8 \mathrm{~m}(\mathrm{n}=55440)$ while in the migration corridor (Figs. 6B \& 8). While a similar per- 


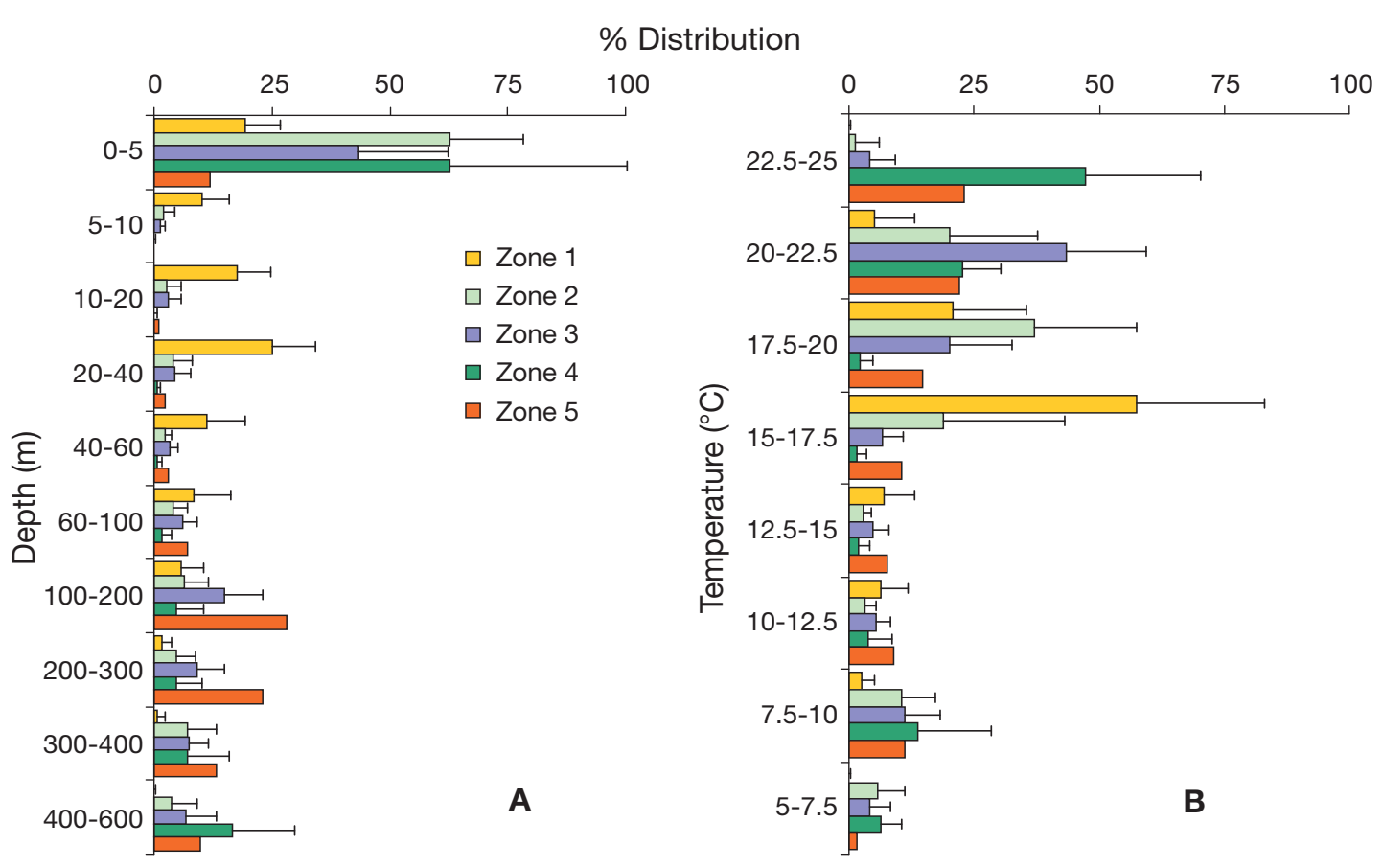

Fig. 7. Carcharodon carcharias. Depth (A) and temperature (B) distributions (\%) for white sharks while at Guadalupe Island (Zone 1, $\mathrm{n}=34$ ), while migrating offshore (Zone 2, $\mathrm{n}=15$ ), while in the Shared Offshore Foraging Area (SOFA, Zone 3, $\mathrm{n}=12$ ), while migrating to Hawaii (Zone $4, \mathrm{n}=2$ ), and while at the Hawaiian Islands (Zone 5, $\mathrm{n}=1$ ). Values are means + SD

centage of time was spent at the surface during the day and at night $(60.3 \%$ between 0 and $5 \mathrm{~m}$ during the day, and $62.4 \%$ at night), deeper dives were made during the day than at night, with $32.8 \%$ of time deeper than $150 \mathrm{~m}$ during the day and only $10.7 \%$ during the night. These diel depth preferences were significantly different (Mann-Whitney rank sum test, p < 0.001).

Sea surface temperatures experienced by sharks in the migration corridor ranged from 16.5 to $23.1^{\circ} \mathrm{C}$ (mean $=19.9 \pm 1.4, \mathrm{n}=44474)$ while overall temperatures experienced by sharks in the corridor ranged from 4.05 to $23.1^{\circ} \mathrm{C}$ (mean $=17.2 \pm 4.8, \mathrm{n}=72577$ ). Analysis of all archival and transmitted tag data showed that white sharks in the migration corridor spent the majority of their time between 0 and $5 \mathrm{~m}$ $(62.6 \%)$ and between 15 and $22.5^{\circ} \mathrm{C}$ (79.3\%) (Fig. 7). Movement to the west occurred at an estimated average speed of $3.2 \pm 1.8 \mathrm{~km} \mathrm{~h}^{-1}(\mathrm{n}=101)$, with a maximum estimated sustained speed to the west over a $24 \mathrm{~h}$ period of $8.0 \mathrm{~km} \mathrm{~h}^{-1}$. The mean time spent moving through the migration corridor was $16.3 \pm 5.9 \mathrm{~d}(\mathrm{n}=15)$.

\section{Zone 3: Shared Offshore Foraging Area}

Movement patterns and utilization of the SOFA

The migration corridor was a conduit to an expansive pelagic habitat encompassing a very large portion of the space between Guadalupe Island and the Hawaiian Islands (Fig. 3). The mean time spent offshore for tag datasets that were long enough to capture the entire migration from Guadalupe Island to the pelagic habitat and back $(n=5)$ was $143.4 \mathrm{~d}(\mathrm{SD}=51.4)$, with a minimum of $86 \mathrm{~d}$ and maximum of $200 \mathrm{~d}$. Pop-up locations for Guadalupe Island tagged sharks and central California tagged sharks (Weng et al. 2007a) were clustered in the same offshore region, the SOFA. This region extends between approximately $32^{\circ}$ and $16^{\circ} \mathrm{N}$ latitude and approximately $128^{\circ}$ and $142^{\circ} \mathrm{W}$ longitude. Fixed kernel analysis of offshore pop-up locations for both Guadalupe sharks and those tagged off California (Weng et al. 2007a) centered the distribution at $25^{\circ} \mathrm{N}$ and $134^{\circ} \mathrm{W}$, which falls over the Molokai Fracture Zone (Fig. 9). A comparison of all calculated male and female track positions within the SOFA showed that the central point for both sexes was within the $25 \%$ contour of the fixed kernel spatial analysis, and within $220 \mathrm{~km}$ of each other. However, there were 3 sharks that spent as long as $67 \mathrm{~d}$ in an area east of the core area ( 2 of these sharks were females number $42 \mathrm{~F}$ and $43 \mathrm{~F}$, while the sex of the third, 9U, was unknown).

To better understand the extent of the SOFA and the dispersal pattern of sharks within this zone, 5 sharks were double-tagged, with the first set of tags programmed to release on 18 May 2006. Four of 5 tags reported as intentionally programmed and, by coincidence, another tag came up prematurely on this date, 

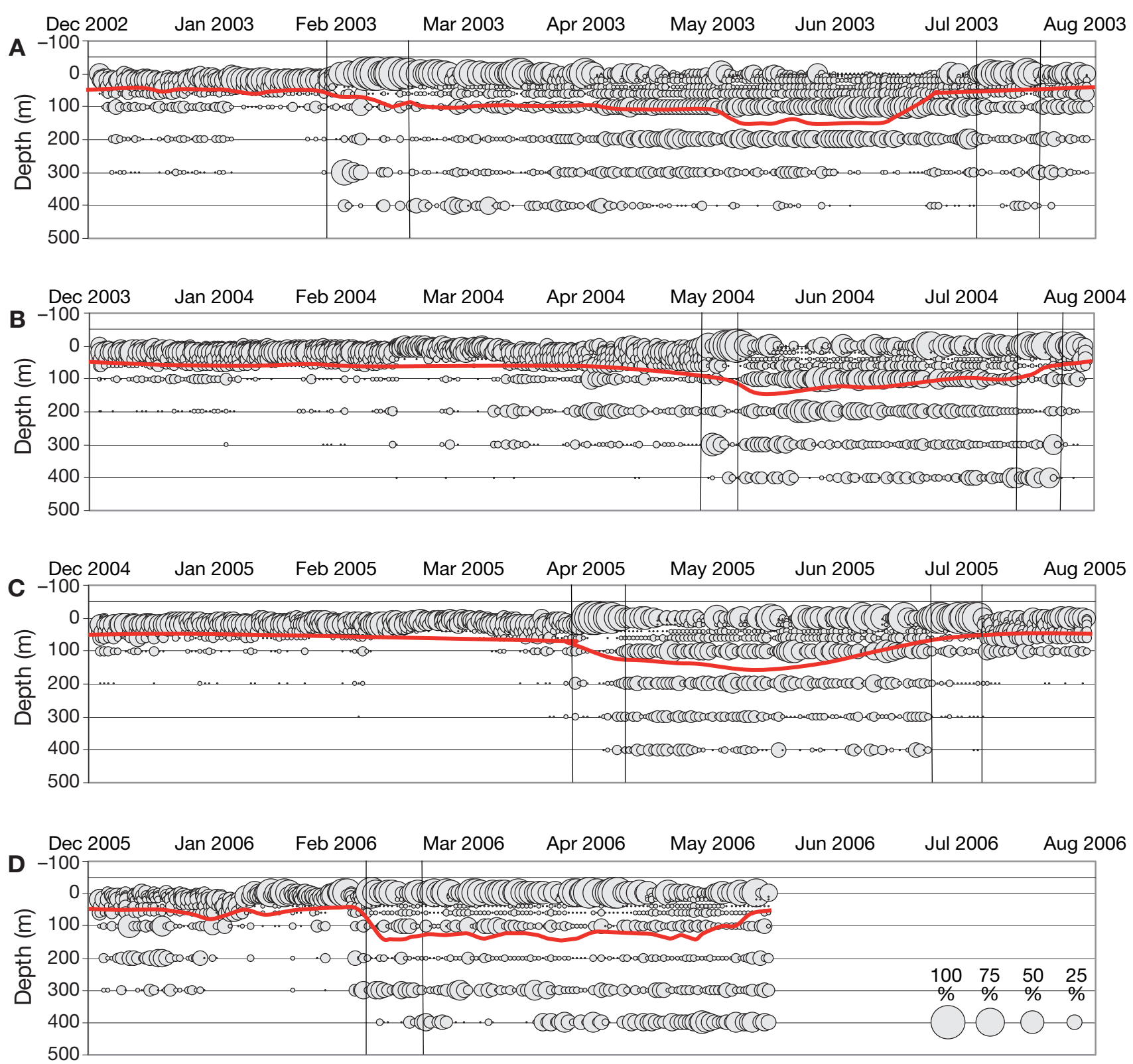

Fig. 8. Carcharodon carcharias. Bubble plots showing percent time at depth for 3 recovered tags that made round-trip migrations from Guadalupe Island to the Shared Offshore Foraging Area (SOFA). (A) Tag 18M, (B) tag 30M, (C) tag 40M and (D) tag 41F. Red line: depth of the mixed layer; vertical lines: time that the shark was migrating offshore. See Table 1 for tag details

providing high resolution locations for 5 individuals. One was in the vicinity of the Hawaiian Islands (3505 km west of Guadalupe Island, 41F), 1 was still near Guadalupe Island $(50 \mathrm{M})$ and the remaining 3 were 1256, 1569, and $1589 \mathrm{~km}$ west of the island $(45 \mathrm{M}$, $46 \mathrm{M}, 48 \mathrm{M}$ ) (Fig. 1). Two of the offshore sharks were separated by only $35 \mathrm{~km}(46 \mathrm{M}$ and $48 \mathrm{M})$. The shark remaining off Guadalupe Island was the individual mentioned above (tag 51M), location data for which indicated that it was still off the island on 22 May 2006 and again on 7 July 2006, with no records in between, so it is unclear whether this shark ever left Guadalupe Island. The shark near the Hawaiian Islands was female and the 4 others were males (Table 1).

Depth and temperature data

Upon arrival at the SOFA, white sharks began a repetitive deep diving pattern, with deeper dives during the day (Fig. 6C). The mixed layer ranged from 60 to $180 \mathrm{~m}$, with an average of $120 \mathrm{~m}$. Data from 4 recov- 


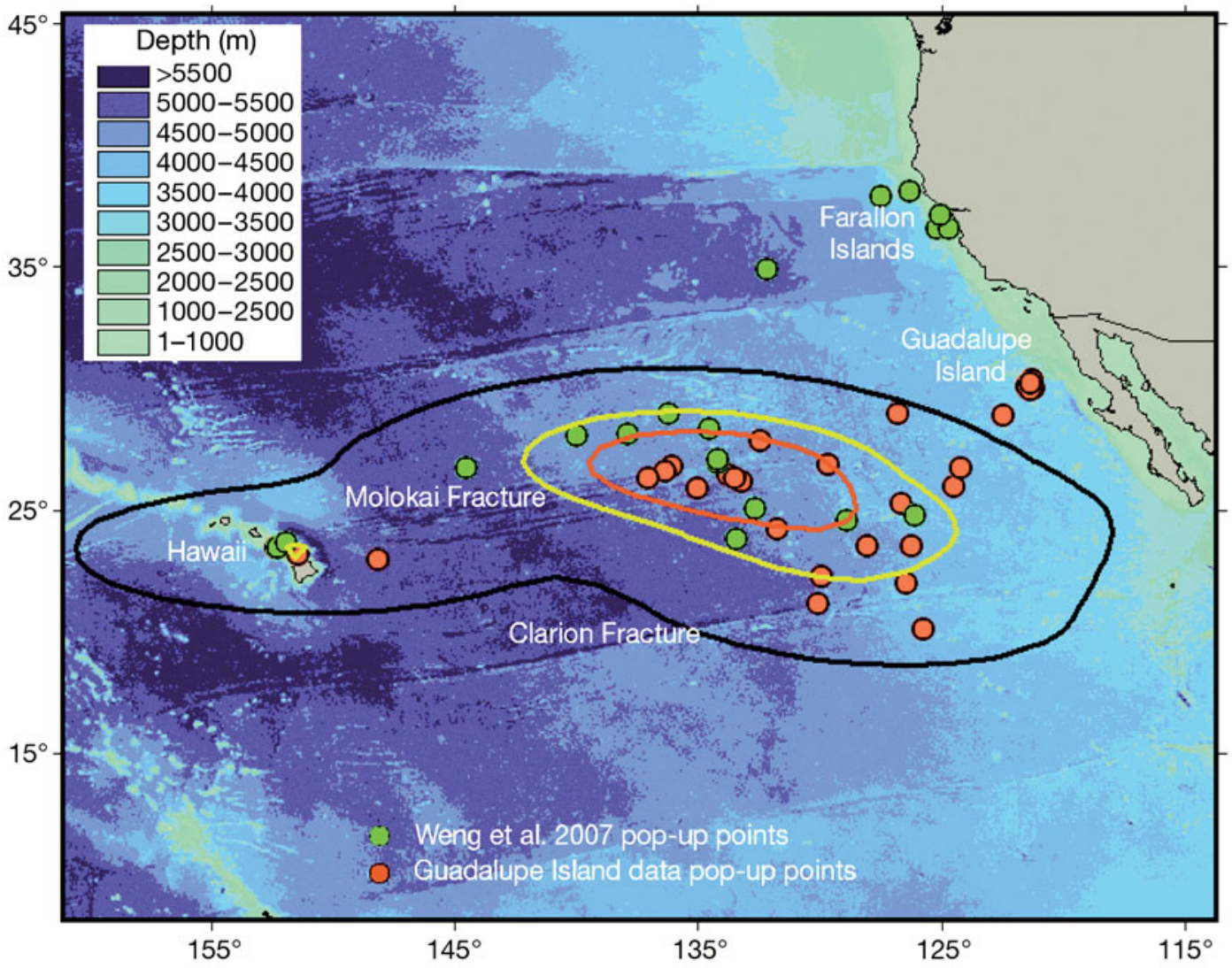

Fig. 9. Carcharodon carcharias. Satellite tag pop-up points for sharks tagged at Guadalupe Island and those tagged in the Farallon Islands (Weng et al. 2007a), with kernel volume contours (red: 25\% contour; yellow: 50\% contour; black: $95 \%$ contour) indicating core use regions for offshore pop-up points from both Guadalupe Island and Farallon Islands shark

ered WC tags showed that, during the night, the sharks spent $28 \%$ of their time between 0 and $5 \mathrm{~m}$ and $62 \%$ at 5 to $200 \mathrm{~m}$. During the day, they spent $30 \%$ of their time between 0 and $5 \mathrm{~m}$, but only $27 \%$ of their time at 5 to $200 \mathrm{~m}$, with $43 \%$ of their time deeper than $200 \mathrm{~m}$. The average depth was $140.7 \pm 143.5 \mathrm{~m}(\mathrm{n}=255758)$. Differences in diel depth preferences were found to be significant (Mann-Whitney rank sum test, p < 0.001).

Sea surface temperatures experienced by sharks in the SOFA ranged from 15 to $25.2^{\circ} \mathrm{C}$ (mean: $20.6 \pm 1.8$, $\mathrm{n}=64773$ ), while overall temperatures experienced by sharks in this area ranged from 3.9 to $25.2^{\circ} \mathrm{C}$ (mean: $16.9 \pm 4.9, \mathrm{n}=255758$ ). Analyzing all tag data, tagged sharks in the SOFA spent $43.5 \%$ of their time between the surface and $5 \mathrm{~m}$, and $38.5 \%$ between 100 to $600 \mathrm{~m}$, and the majority of their time was spent at temperatures between 17.5 and $22.5^{\circ} \mathrm{C}(66.0 \%)$ (Fig. 7).

\section{Zones 4 and 5: The Hawaiian Islands}

Over the duration of the study, a total of 3 white sharks moved from Guadalupe Island to the vicinity of the Hawaiian Islands (note that in Fig. 1, there are 4 tags near Hawaii, but 2 of these were on the same shark). In August of 2003, a tag from a shark of unknown sex popped up just south of Lanai (tag 19U) and provided a pop-up location, but no other usable data. In 2005, 2 sharks traveled to the island of Hawaii (the male with tag 53M arrived in March and the female with tag $42 \mathrm{~F}$ popped up $155 \mathrm{~km}$ east in May) (Fig. 1). The photo-ID monitoring program (Domeier \& Nasby-Lucas 2007) did not identify either of these sharks at Guadalupe Island in the following autumn (2006). The male had been present off Guadalupe Island in the autumns of 2004 and 2005 and was sighted again in 2007, while the only year the female was seen at the island was in autumn 2005. Both of these sharks began their offshore migration at about the same time, but they arrived at the Hawaiian Islands 2 mo apart (Table 1, Fig. 4). Tag 42F spent 54 d east of the core area of the SOFA prior to continuing west (Fig. 2D), while tag 53M passed through the SOFA and continued on directly to the Hawaiian Islands.

While traveling between the SOFA and the Hawaiian Islands, sharks spent the majority of their time at the surface during the night, with frequent deep dives below the mixed layer during the day. The mixed layer 
in this zone ranged from $115 \mathrm{~m}$ to $175 \mathrm{~m}$ with an average of $145 \mathrm{~m}$. Data from the recovered tag showed that there was a significant difference in diel behavior (Mann-Whitney rank sum test, p <0.001). This shark spent $23 \%$ of its time during the day and $52 \%$ at night between 0 and $5 \mathrm{~m}$, and spent $74 \%$ of its time during the day deeper than $150 \mathrm{~m}$, with only $24 \%$ of time spent at this depth at night. Analysis of the bin data from both tags that traveled to the Hawaiian Islands showed that, while traveling, the sharks spent $62.8 \%$ of their time between 0 and $5 \mathrm{~m}, 28.6 \%$ below $200 \mathrm{~m}$, and $47.4 \%$ of their time in water between 22.5 and $25^{\circ} \mathrm{C}$ (Fig. 7).

Only one tag provided good data detailing the behavior of a shark over the shelf waters of Hawaii; these data show that it spent the majority of its time in deeper water. Analysis of the binned data showed $11.7 \%$ of time spent at the surface and $74.39 \%$ below $100 \mathrm{~m}$, with only $23.0 \%$ of time spent in the warmer waters between 22.5 and $25^{\circ} \mathrm{C}$ (Fig. 7), reflecting the increased time spent at depth.

\section{Evidence of philopatry}

Two male sharks identified through photo-ID were tagged in two consecutive years; both sharks made round trip migrations each year. Shark \#19 from the Guadalupe Island photo-ID catalog (Domeier \& NasbyLucas 2007) was tagged in December 2002 (WC tag $18 \mathrm{M})$ before leaving the island on 2 February 2003; it returned on 28 July 2003 and the tag was recovered on 8 August 2003. Shark \#19 was retagged in August 2003 (WC tag 21M) and again in December 2003 (MT tag 28M) before leaving the island around 2 February 2004. The WC tag transmitted in April 2004 and the MT tag transmitted in August 2004. The MT tag transmitted very few data, but did provide 2 location points showing that the shark returned to Guadalupe Island no later than 14 July 2004 (Fig. 10). Shark \#19 was away from the island for $176 \mathrm{~d}$ in 2003 and then in the vicinity of Guadalupe Island for $188 \mathrm{~d}$ before departing again for approximately 163 d (Fig. 10). In both years, shark \#19 traveled to a maximum calculated longitude of 139 to $141^{\circ} \mathrm{W}$ and, interestingly, it left the island on the same date each year, although it returned at least 2 wk earlier in 2004 than in 2003. The time spent in the insular versus pelagic phases were almost equal, with $48 \%$ of time spent away from the island the first year and no more than $45 \%$ the second year.

Shark \#10 from the photo-ID catalog was also tagged in consecutive years and each tag was recovered off Guadalupe Island the following August. Shark \#10 was tagged in December 2003 (WC tag 30M) and left Gua-

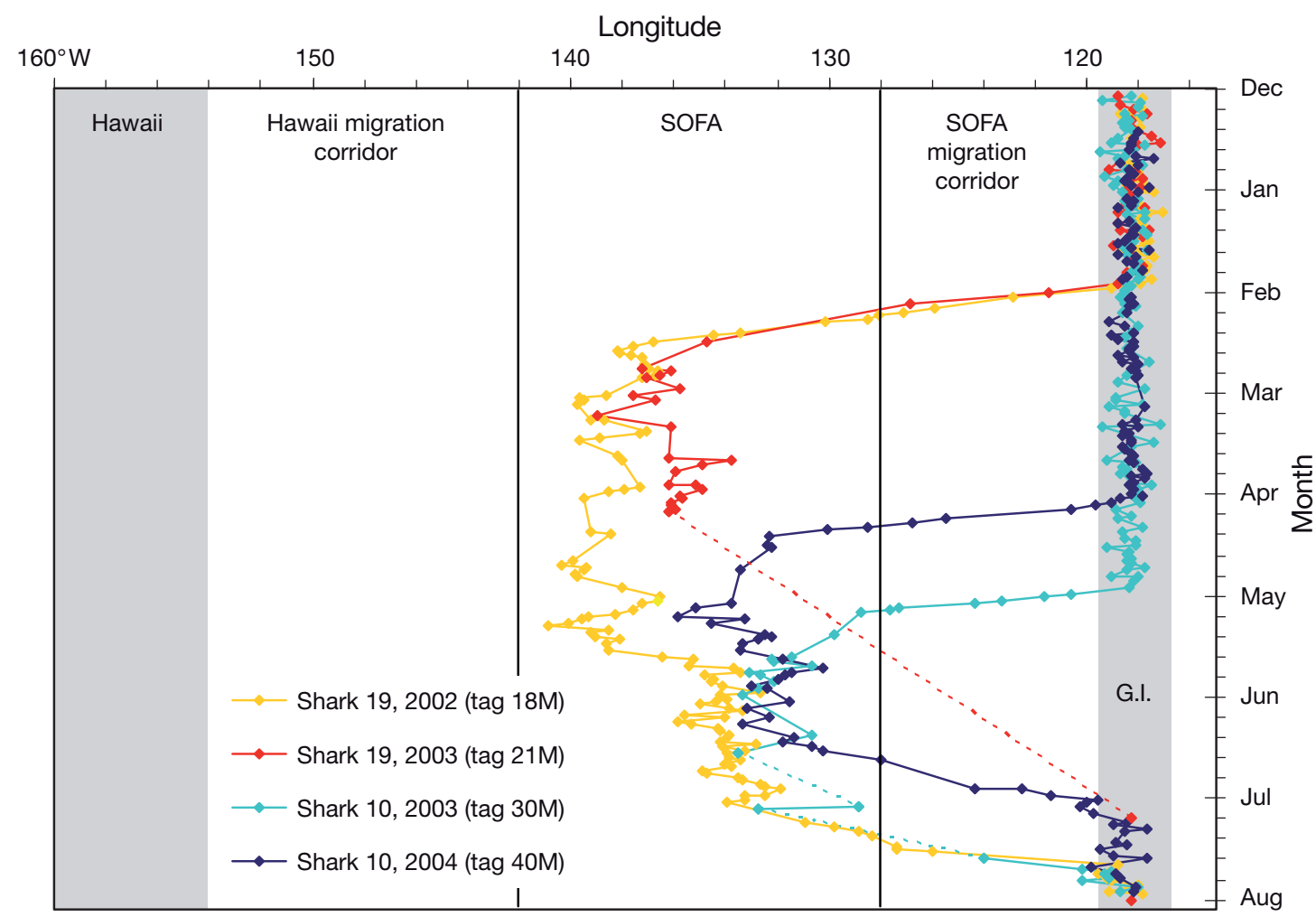

Fig. 10. Carcharodon carcharias. Plot of longitudinal movement versus date for 2 individuals tagged at Guadalupe Island in 2 successive years. G.I.: Guadalupe Island 
dalupe Island on 5 May before returning on 30 July 2004. The first tag was removed on 6 August 2004 and a second tag deployed on 12 December 2004 (WC tag 40M). In 2005, shark \#10 left the island on 7 April, returned on 8 July and the tag was recovered on 8 August (Fig. 10). It was away from the island for $86 \mathrm{~d}$ in 2004 and then in the vicinity of Guadalupe Island for $251 \mathrm{~d}$ before departing again for $92 \mathrm{~d}$ (Fig. 10). In both years, the shark traveled to a maximum calculated longitude of 133 to $135^{\circ} \mathrm{W}$. The departure date in 2005 was 28 d earlier than in 2004, and the shark returned to the island approximately $22 \mathrm{~d}$ earlier than in the previous year. The amount of time spent in the insular versus pelagic habitats was very different from that of shark \#19, yet consistent between years for this shark, with $24 \%$ of time spent away from the island the first year and $25 \%$ the second year.

Of the 7 sharks that retained their tags until at least August, 5 returned to Guadalupe Island (4 males and a sexually immature female of $3.2 \mathrm{~m}$ length) and 2 were still in the SOFA (1 shark of unknown sex was in Hawaii mid August of 2003 and 1 sexually mature female of $4.9 \mathrm{~m}$ length was $1392 \mathrm{~km}$ west of Guadalupe Island on 11 September 2005) (Fig. 4). The female shark that was still in the SOFA in September was not sighted off Guadalupe Island using photo identification methods during autumn or winter of 2005, but was sighted off the island during autumn of 2006.

\section{DISCUSSION}

Electronic tagging of white sharks Carcharodon carcharias at Guadalupe Island, Mexico, demonstrated that this group spends approximately half of the year aggregated in an insular habitat prior to migrating and dispersing to a large pelagic environment for the remainder of the year. Data showed that these sharks spend autumn and winter off Guadalupe Island, begin an offshore migration in late winter to early spring, spend spring and summer offshore, and return to Guadalupe Island in late summer. This seasonal migration pattern was similar to that of a separate white shark aggregation from central California, USA, which travels to precisely the same pelagic habitat (Fig. 8) (Boustany et al. 2002, Weng et al. 2007a), a region we have termed the Shared Offshore Foraging Area (SOFA).

For the first time, individual white sharks were tagged in successive years, allowing us to confirm that migratory patterns and behaviors are repeated. This study, in conjunction with a previous photo-ID study (Domeier \& Nasby-Lucas 2007), demonstrates that white sharks can express strong philopatry for Guadalupe Island. Interestingly, 2 male sharks tagged in successive years exhibited repeated individual preferences in the extent of their westward movements and times spent within the SOFA, indicating that individual white sharks may also have consistent behavioral differences in timing and lengths of their offshore migrations, as well as preferences for specific sub-regions of the SOFA.

\section{Guadalupe Island, migration corridor, SOFA and Hawaii}

Tagging data from Guadalupe Island white sharks indicated that individuals near the island remain primarily in the mixed layer, with more time spent at the surface and deeper dives during the day than at night. This diving behavior is likely consistent with a hunting strategy for pinnipeds. Motivation for departure from the island may be linked to the declining presence of prey. Male fur seals depart Guadalupe Island soon after mating (August), but timing of departure for females and pups occurs much later, and is not well documented (Pierson 1978). Guadalupe Island white sharks may be preying upon yellowfin tuna (Domeier \& Nasby-Lucas 2007), which also depart as the water cools. Individual white sharks are likely choosing a departure time that is relative to their specific hunting success and physiological condition. Without exception, every shark that we tagged and from which we received continuous data between the months of December and July migrated west for a portion of that period. The possibility remains that some white sharks reside at Guadalupe year-round, but if so, it must be a rare occurrence.

Upon beginning their migration, the sharks remained very close to the surface as they traveled offshore, making only a few dives, usually during daylight hours. Whether these dives are for navigational orientation, thermoregulation or prey searching is not known. Estimates in location and speed indicate that the sharks exhibited directed swimming behavior and that this area is used as a migration corridor as individuals move on their way to the SOFA. Similar migration behavior for white sharks was reported by Bonfil et al. (2005) and Weng et al. (2007a).

Once in the SOFA, the white sharks began a routine comprised of extremely frequent deep dives, sometimes in excess of $980 \mathrm{~m}$. This diving occurred primarily during the day, with the sharks spending much of their time below the mixed layer. The fact that the individuals spent many months at sea exhibiting this type of diving behavior strongly suggests that it is for the purpose of feeding. Squid, swordfish and other sharks are possible prey items; most other large pelagic fishes (tunas, marlins) do not spend much time at the depths 
to which white sharks dive. Stable isotope studies may provide information on the nature of prey items consumed offshore, but sampling muscle from a large shark is difficult due to their thick skin.

The offshore zone consists of a wide region of seafloor containing relatively large changes in vertical relief before dropping to an abyssal plain that extends to Hawaii. Pop-up points for sharks that had migrated offshore from central California (Weng et al. 2007a) and Guadalupe Island were centered over the Molokai fracture zone, spread out along the border between the seamounts and abyssal plain (Fig. 9). This edge between a region of vertical relief and the flat seafloor likely features increased productivity and provides enhanced foraging opportunities (Holland \& Grubbs 2007, White et al. 2007). From there, sharks may follow the geomagnetic signal along the Molokai Fracture directly to the Hawaiian Islands (Meyer et al. 2005). Geolocation estimates of latitude are not precise enough to confirm this as a route to and from Hawaii, but future tags that measure the earth's magnetic field might test this hypothesis.

Three sharks tagged at Guadalupe Island migrated to the Hawaiian Islands, a destination also reported for white sharks tagged off central California (Boustany et al. 2002, Weng et al. 2007a). Although Guadalupe Island sharks are capable of reaching Hawaii, our data show that the majority of migrations stopped well short of Hawaii, very similar to tagging results from central California (Weng et al. 2007a). These longrange migrations require an accurate navigational ability as well as dramatic shifts in behavior, temperature/depth regimes and very likely prey. Food is also the most probable motivating factor for movement from the SOFA to Hawaii. The arrival of sharks off Hawaii (from both California and Mexico) occurs during the calving period of humpback whales Megaptera novaeangliae in Hawaiian waters in November and May (Taylor 1985).

\section{Connectivity of eastern Pacific white shark populations}

The discovery that adult white sharks tagged at Guadalupe Island share pelagic space with conspecifics from central California warrants a discussion of connectivity between these 2 groups. Guadalupe Island and central California white sharks inhabit disjunct coastal habitats; we have never tracked a shark from Guadalupe Island to central California, nor vice versa. By programming multiple tags to pop up on the same date we demonstrated that, although white sharks from each of these regions travel to the SOFA, the sharks are widely dispersed while in this zone and may rarely come into close contact. Two other labels have been suggested for the SOFA, i.e. White Shark Café (www.topp.org) and Offshore Focal Area (Weng et al. 2007a). These terms suggests a gathering or concentration of sharks, when in fact the pelagic habitat of these sharks is diffuse and cannot be considered an aggregation site. The true aggregation sites are off Guadalupe Island, the Farallon Islands and the coastal site at Año Nuevo, California. Genetic mixing between these geographically separated populations would require mating encounters in the SOFA or movement of juvenile sharks between these regions. Both are possible, but the latter is more plausible. Although adult and sub-adult white sharks occur off Guadalupe Island, small juveniles have not been observed. It is not known how sharks recruit to the island, nor is it known how or why they learn to migrate into the middle of the Pacific.

The motivation for migration to the SOFA is unknown, but most theories include mating or foraging. Reddened claspers (indicative of recent mating) have never been observed on male white sharks off Guadalupe Island, so it is possible that mating occurs in the SOFA. However, males and females are in convenient close proximity off Guadalupe Island relative to their wide dispersion while offshore. Migration to the SOFA was undertaken by all individuals (both mature and immature) for which we have continuous position data, which is inconsistent with a migration purely for reproductive purposes. The presence of natal-sized white sharks in the nearshore waters of California (Dewar et al. 2004, Weng et al. 2007b) also suggests that parturition more likely occurs nearshore rather than in the SOFA. Electronic tagging data point to foraging as the motivation for white shark migration. Diving behaviors of sharks in the SOFA from both Guadalupe Island and central California (Boustany et al. 2002, Weng et al. 2007a) are strongly suggestive of feeding behavior. This hypothesis is further supported by the fact that sharks returning from the SOFA are not noticeably thin.

White sharks from both Guadalupe Island and the Farallon Islands appear to have similar spatial and temporal behavior patterns. Comparison of depth and temperature data collected from satellite-tagged Guadalupe Island white sharks are similar to those reported from sharks tagged in northern California (Boustany et al. 2002, Weng et al. 2007a), but did show some difference in behavioral patterns. Analysis of depth data from tags recovered from Guadalupe Island sharks indicated a significant difference in diel behavior in all zones, with consistently more time spent in the mixed layer during the night and more excursions below the mixed layer during the day. In the nearshore environment and migration corridor, this differed from the report of Weng et al. (2007a), who found no signif- 
icant difference in diel behavior. This may be related to the colder water $\left(5\right.$ to $9^{\circ} \mathrm{C}$ cooler) and shallower mixed layer (average $34 \mathrm{~m}$ shallower) experienced by sharks tagged in the Farallon Islands (Weng et al. 2007a). However, temperatures and depths of the mixed layer experienced while traveling were similar for both groups of sharks, so it remains unclear why behavior differed between studies.

\section{Limitation of geolocation algorithms and value of pop-up positions}

Given the imprecision of geolocation estimates derived from light- and SST-based algorithms, our best indicators of spatial utilization are the pop-up positions of the tags. These positions are extremely accurate (within 150 to $1000 \mathrm{~m}$ ), and the sheer number of popup points generated from this study is enough for 2 significant conclusions. First, white sharks remain in close proximity to Guadalupe Island prior to the migration and pelagic cycle. This is evident from the fact that every tag that popped up during autumn and winter months was located off the island; none occurred off mainland Mexico or USA. Second, the distribution of offshore tag pop-ups was much more clumped than all geolocation estimates (Fig. 1). We believe that the large number of points generated by plotting our pop-up locations, along with those published by Weng et al. (2007a), is much more representative of the SOFA than the data derived from geolocation algorithms and subsequent fixed kernel analyses. Pop-up positions were confined to the north and south between $28^{\circ}$ and $16^{\circ} \mathrm{N}$ latitude, and none appeared east of Guadalupe Island or west of the Hawaiian Islands.

Twenty-one pop-up positions around Guadalupe Island provide preliminary data on the spatial distribution of sharks around the island. They were clustered at our study sites and along the southwestern side of the island. A large number of Guadalupe fur seals occur at both study sites, while elephant seals are also present at the northern study site. It is not known whether there is a significant number of seals on the southwestern side of the island; since this side is exposed to wind and waves, it is much more difficult to conduct research activities.

Our algorithm-derived location estimates for white sharks tagged at Guadalupe Island have, on many occasions, placed sharks in the coastal waters of Los Angeles and Long Beach, California; these are likely artifacts of the SST matching algorithm attempting to match temperatures when there is insufficient SST imagery in the region around Guadalupe Island. Guadalupe Island is often shrouded in clouds, causing even blended or smoothed SST imagery to have gaps near the island. As a result, the matching algorithm selects SST pixels within the ports of Los Angeles and Long Beach, industrial areas on the same line of longitude as Guadalupe that have elevated SSTs that are often similar to those found far to the south off Guadalupe Island. A filter could be placed on the algorithm to prevent selection of points near Los Angeles, but this requires an assumption that such a movement would never occur.

Although approximately 10 location estimates were plotted near the coast of Baja California, Mexico, east of Guadalupe Island, these location estimates are also very suspect. All of these points were derived from MT tag data. Microwave telemetry does not share its geolocation algorithm with researchers, so we do not have control over their process for estimating geographic positions. We have found MT longitudes to be much more erratic and we suspect that they are more prone to error than WC tags, despite the obvious smoothing applied by the manufacturer. Unfortunately, the technology of geolocation estimation is still burdened with error.

\section{Sex-specific differences in movement patterns}

Sex-specific differences in migratory patterns occur, but data are not sufficient to infer cause and effect. We confirmed gender differences in the timing of eastward migration and return to Guadalupe Island. The arrival of tagged males to the island was very consistent, with individuals returning within a $2 \mathrm{wk}$ period at the end of July. Return trip data for females are scarce, but Domeier \& Nasby-Lucas (2007) found that females return later than males, or not at all in the case of mature females (in consecutive years). One tagged $3.2 \mathrm{~m}$ female returned to Guadalupe Island before October. Another tagged $4.9 \mathrm{~m}$ female was found in the pelagic zone as late as September, and combining the tagging data with the photo-ID data indicates that this shark did not return until the following year. The return of male sharks to Guadalupe Island coincides with the pupping of Guadalupe fur seals (Pierson 1978). It is unclear why females would arrive later to exploit this prey resource.

Anderson \& Pyle (2003) speculated that the everyother-year occurrence of individual female white sharks at the Farallon Islands may be due to an extended reproductive cycle. Our data support the speculation of Mollet et al. (2000) that white sharks have a prolonged gestation period (>18 mo). Although females have been sighted in successive years off Guadalupe Island, these sharks are likely immature; the largest females sighted at Guadalupe Island have only been recorded every other year (Domeier \& 
Nasby-Lucas 2007). The every-other-year visitation pattern for sexually mature females may also explain why there is a smaller percentage of sexually mature females than males in our tagging sample.

Although the seasonal arrival of white sharks off Guadalupe Island differed for males and females, there was no apparent difference between the sexes in the timing of westward migration and offshore destination. It is noteworthy that, although the mean departure date for males and females was the same, the actual span of departure dates was much greater for males than females. Two females and a shark of unidentified sex were found to travel to an offshore area that was south and east of the common area where all sharks had been tracked. One of these females then continued its migration on to Hawaii. Unfortunately, we have very few data on females, so it is not possible to determine whether they occupy different areas of the SOFA. Increased tagging data on females will help address these questions.

\section{Summary}

Electronic tagging of white sharks has been a very effective method for redefining what we know about this threatened species. White sharks appear to be very adaptive to regional environments and do not behave similarly throughout their range. The longterm utilization of the pelagic environment has now been well documented in the eastern Pacific, but migratory patterns and habitat utilization appear to be different in other parts of the world. Three longdistance return migrations have been reported for sharks tagged off South Africa. In this case, 2 sharks remained within the coastal waters of the western Indian Ocean and the third shark migrated across the Indian Ocean to the coastal waters of Western Australia (Bonfil et al. 2005). This third shark did not linger in the offshore environment, indicating that the coastal waters of Australia were the destination, rather than the pelagic habitat. White sharks tagged in Australia similarly remained in the coastal environment (Bruce et al. 2006). Whether or not long-term residence in pelagic environments is specific to the eastern Pacific population of white sharks or common across the globe has yet to be addressed.

This study represents the largest sample of electronically tagged white sharks in the world to date. The tagging data combined with previous and ongoing photo-ID monitoring of the same individuals has allowed a very unique perspective on the natural history of this species in the eastern Pacific. Additional tagging of adult females will answer some of the remaining questions on sex-specific migration patterns.
Tagging studies of juveniles along the mainland coasts of Mexico and the United States may lead to an understanding of how sharks recruit to the adult aggregation sites. The development and application of higher spatial resolution tag technology in the future will allow study of the interaction of individuals and specific use of habitat and space around Guadalupe Island.

Acknowledgements. This research was supported by grants from the George T. Pfleger Foundation and the Offield Family Foundation. We thank the dedication and field work of T. Pfleger. We also thank H. Dewar, C. Sepulveda, and C. Fischer for their assistance in this project. We thank F. Galván Magaña and M. Hoyos Padilla for Mexican permitting support. Research was conducted in accordance with permits through SEMARNAT (Secretaría de Medio Ambiente y Recursos Naturales) and CONANP (Comisión Nacional de Áreas Naturales Protegidas).

\section{LITERATURE CITED}

Ainley DG, Henderson RP, Huber HR, Boekelheide RJ, Allen SG, McElroy TL (1985) Dynamics of white shark/pinniped interactions in the Gulf of the Farallones. Mem South Cal Acad Sci 8:109-122

Anderson SD, Pyle P (2003) A temporal, sex-specific occurence pattern among white sharks (Carcharodon carcharias) at the South Farallon Islands, California. Calif Fish Game 89:96-101

Bonfil R, Meyer M, Scholl MC, Johnson R and others (2005) Transoceanic migration, spatial dynamics, and population linkages of white sharks. Science 310:100-103

Boustany AM, Davis SF, Pyle P, Anderson SD, Le Boeuf BJ, Block BA (2002) Expanded niche for white sharks. Nature 415:35-36

- Bruce BD (1992) Preliminary observations on the biology of the white shark Carcharodon carcharias in south Australian waters. Aust J Mar Freshw Res 43:1-11

Bruce BD, Stevens JD, Malcolm H (2006) Movements and swimming behaviour of white sharks (Carcharodon carcharias) in Australian waters. Mar Biol 150:161-172

Cailliet GM, Natanson LJ, Weldon BA, Ebert DA (1985) Preliminary studies on the age and growth of the white shark Carcharodon carcharias, using vertebral bands. Mem South Cal Acad Sci 9:49-60

Compagno LJV (1984) FAO Species Catalogue. Vol 4. Sharks of the world. An annotated and illustrated catalogue of shark species known to date. Part 1: Hexanchiformes to Lamniformes. FAO Fish Synop 125:1-249

Compagno LJV (2001) Sharks of the World. An annotated and illustrated catalogue of the shark species known to date. Vol 2. Bullhead, mackerel and carpet sharks (Heterodontiformes, Lamniformes and Orectolobiformes). FAO Species Catalogue for Fisheries Purposes No 1, Vol 2. FAO, Rome

Dewar H, Domeier M, Nasby-Lucas N (2004) Insights into young of the year white shark, Carcharodon carcharias, behavior in the southern California bight. Environ Biol Fishes 70:133-143

> Domeier ML, Nasby-Lucas N (2007) Annual re-sightings of photographically identified white sharks (Carcharodon carcharias) at an eastern Pacific aggregation site (Guadalupe Island, Mexico). Mar Biol 150:977-984

Domeier ML, Kiefer D, Nasby-Lucas N, Wagschal A, O'Brien 
F (2005) Tracking Pacific bluefin tuna (Thunnus thynnus orientalis) in the northeastern Pacific with an automated algorithm that estimates latitude by matching sea-surfacetemperature data from satellites with temperature data from tags on fish. Fish Bull 103:292-306

Ferreira CA, Ferreira TP (1996) Population dynamics of white sharks in South Africa. In: Klimley AP, Ainley DG (eds) Great white sharks: the biology of Carcharodon carcharias. Academic Press, San Diego, CA, p 381-391

Francis MP (1996) Observations on a pregnant white shark with a review of reproductive biology. In: Klimley AP, Ainley DG (eds) Great white sharks: the biology of Carcharodon carcharias. Academic Press, San Diego, CA, p 157-172

Hilton-Taylor C (2000) 2000 IUCN Red List of threatened species. IUCN, Gland and Cambridge

Holland KN, Grubbs RD (2007) Fish visitors to seamounts: tunas and billfish at seamounts. In: Pitcher TJ, Morato T, Hart PJB, Clark MR, Haggan N, Santos RS (eds) Seamounts: ecology, conservation and management. Fish and aquatic resources series, Blackwell Scientific, Oxford, p 189-201

Klimley AP (1985) The areal distribution and autoecology of the white shark, Charcharodon carcharias, off the west coast of North America. Mem South Cal Acad Sci 9:15-40

Meyer CG, Holland KN, Papastamatiou YP (2005) Sharks can detect changes in the geomagnetic field. J R Soc Interface 2:129-130

Mollet HF, Cliff G, Pratt HL Jr, Stevens JD (2000) Reproductive biology of the female shortfin mako, Isurus oxyrinchus Raninesque, 1810, with comments on the embryonic development of lamnoids. Fish Bull 98:299-318

Pierson MO (1978) A study of the population dynamics and

Editorial responsibility: John Choat,

Townsville, Queensland, Australia breeding behavior of Guadalupe fur seal, Arctocephalus townsendi. PhD dissertation, Scripps Institute of Oceanography, University of California, San Diego

Pratt HL Jr (1996) Reproduction in the male white shark. In: Klimley AP, Ainley DG (eds) Great white sharks: the biology of Carcharodon carcharias. Academic Press, San Diego, CA, p 131-138

Rodgers AR, Carr AP (1998) HRE: The home range extension for ArcView. Ontario Ministry of Natural Resources, Centre for Northern Forest Ecosystem Research, Thunder Bay

Smith SE, Au DW, Show C (1998) Intrinsic rebound potentials of 26 species of Pacific sharks. Mar Freshw Res 49: $663-678$

Taylor L (1985) White sharks in Hawaii: historical and contemporary records. Mem South Cal Acad Sci 9:41-48

Weng KC, Boustany AM, Pyle P, Anderson SD, Brown A, Block BA (2007a) Migration and habitat of white sharks (Carcharodon carcharias) in the eastern Pacific Ocean. Mar Biol 152:877-894

> Weng KC, O'Sullivan JB, Lowe CG, Winkler CE, Dewar H, Block BA (2007b) Movements, behavior and habitat preferences of juvenile white sharks Carcharodon carcharias in the eastern Pacific. Mar Ecol Prog Ser 338:211-224

White M, Bashmachnikov I, Arístegui J, Martins A (2007) Physical processes and seamount productivity. In: Pitcher TJ, Morato T, Hart PJB, Clark MR, Haggan N, Santos RS (eds) Seamounts: ecology, conservation and management. Fish and aquatic resources series, Blackwell Scientific, Oxford, p 65-84

> Worton BJ (1989) Kernel methods for estimating the utilization distribution in home-range studies. Ecology 70 : $164-168$

Submitted: September 19, 2007; Accepted: June 30, 2008

Proofs received from author(s): October 17, 2008 